\title{
PENGEMBANGAN SISTEM ADMINISTRASI SEKOLAH BERBASIS TEKNOLOGI INFORMASI DI MTS. DARUL ULUM DAN MTS. MIFTAHUL HUDA DI KABUPATEN JEPARA
}

\author{
Miftah Arifin dan Aida Nahar \\ Universitas Islam Nahdlatul Ulama Jepara \\ email: miftah012001@ gmail.com \\ email: aidastienu@gmail.com
}

Keywords:

school

administration, information

technology, system administration, school,

\author{
Kata Kunci: \\ Administrasi \\ sekolah, teknologi \\ informasi, system \\ administrasi
}

\begin{abstract}
This purpose of this activity are, first, provide companionship to the school administration system integrated to provide quick, effective and accurate services. Second, fix the quality management system of institutional to reach the school's objectives. The method used are training, FGD, and Mentoring. The result show that, first, preparation Integrated School Administration System (SISDU) goes well. Obstacles encountered in the implementation of the infrastructure that SISDU is still limited and the ability of teachers to operate system needs to be improved. Second, the activities preparation of ISO-based governance system in general has been running well, but school administrators are still unfamiliar about the documents in the ISO standardize, they are already accustomed to using predefined Education Offices' documents.
\end{abstract}

\begin{abstract}
Abstrak
Tujuan kegiatan ini ini, pertama, memberikan pendampingan terhadap sistem administrasi sekolah terintegrasi untuk memberikan layanan yang cepat, efektif dan akurat. Kedua, memperbaiki sistem manajemen mutu kelembagaan untuk mencapai tujuan sekolah. Metode yang digunakan adalah pelatihan, FGD, dan Mentoring. Hasil penelitian menunjukkan bahwa, pertama, persiapan Sistem Administrasi Sekolah Terpadu (SISDU) berjalan dengan baik. Kendala yang dihadapi dalam pelaksanaan infrastruktur yang SISDU masih terbatas dan kemampuan guru untuk mengoperasikan sistem perlu ditingkatkan. Kedua, persiapan kegiatan sistem pemerintahan berbasis ISO secara umum telah berjalan dengan baik, tetapi administrator sekolah masih asing tentang dokumen dalam ISO standarisasi, mereka sudah terbiasa menggunakan dokumen yang telah ditetapkan oleh Dinas Pendidikan.
\end{abstract}

